\begin{tabular}{|c|c|c|}
\hline $\bar{\sigma}$ & International Journal of Current Research in & \\
\hline & $\begin{array}{c}\text { Biosciences and Plant Biology } \\
\text { BSs }\end{array}$ & \\
\hline $\begin{array}{l}\text { EXCELLENT } \\
\text { PUBLISHERS }\end{array}$ & $\begin{array}{l}\text { J (Unme) } \\
\text { Journal homepage: www.ijcrbp.com }\end{array}$ & 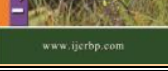 \\
\hline
\end{tabular}

\title{
Study on the Age and Growth of Marine Gastropod Ficus ficoides (Lamarck 1822) from Thirumullaivasal, Southeast Coast of Tamil Nadu, India
}

\author{
K. G. Selvi* and P. Jeevanandham \\ PG and Research Department of Zoology, T.B.M.L. College, Porayar-609 307, Tamil Nadu, India \\ *Corresponding author.
}

\begin{abstract}
The Von Bertalanffy growth parameters were performed by length based method to determine the age of the Ficus ficoides. Three parameters have been estimated and that the values of male $F$. ficoides was $\mathrm{L}_{\infty}=73 \mathrm{~mm}$ and $74 \mathrm{~mm}$ for female, the age at the origin of the growth curve $\left(\mathrm{t}_{\mathrm{o}}\right)$ for male $2.67 \mathrm{~mm}$ and for female was $2.78 \mathrm{~mm}$ and estimated co-efficient of catabolism (k) was 0.280 and 0.282 for male and female respectively. Male attained a length of $32.93,64.05,70.9,72.89 \mathrm{~mm}$ in $0.08,0.3$, $0.5,1.08$ years. The females recorded a growth of $33.4,68.5,72.77,73.89 \mathrm{~mm}$ in the year0.08, $0.4,0.7,1.08$ years respectively. The growth performance index $(\varphi$ ') was 3.72 for male and 3.74 for female. FiSAT package ELEFAN-I attempted and the highest score obtained was $0.196\left(\mathrm{k}=0.430\right.$ year $\left.^{-1} ; \mathrm{Rn}=0.093, \mathrm{SL}=37.50\right)$ for male and it was $0.253\left(\mathrm{k}=0.789\right.$ year $\left.^{-1} ; \mathrm{Rn}=0.098 ; \mathrm{SL}=42.50\right)$ for female. The life span $\left(\mathrm{T}_{\max }\right)$ estimated is 3.84 years for male and 6.97 years for female. The present study age and growth estimated in comparison with existing evidences.
\end{abstract}

\section{Article Info}

Accepted: 10 May 2016

Available Online: 06 June 2016

Ke y w o r d s

Catabolism

Ficus ficoides

Growth index

Marine gastropod

Von Bertalanffy

\section{Introduction}

Age and growth of the animals are interrelated phenomena which denote the duration of life spent by the individual (age) and the increase in its volume or mass (growth). Growth is a complex process. Size is an immediately perceptible and intuitively important feature of an organism. Pitiwong (1991) defined growth rate as the change in the body mass or weight over time. The rate at which size is attained and the influence of environmental fluctuation on this process play an important role in ecology (Christensen, 1994). The Family: Ficidae (fig shell) are found in all the habitats. The distribution and habits of gastropods are influenced by environmental conditions, which vary with not only with latitude but also with habitat. The influence of the habitat on the shape of the shell in marine gastropod has been studied by several workers. The shell growth in molluscs related to environmental conditions was explained by Liu and Wang (1999).

Study on the age and growth reveals the age of sexual maturity and the age at which marketable size is attained. Growth trajectories tend to follow characteristic patterns. Often, but not always, growth is rapid at first and then levels off later in the life of an animal to approach an apparent asymptote. A number of mathematical models behaving in similar ways have been proposed as formal description of these patterns namely the Von Bertalanffy equation. 
There are many analytical tools that can be applied in assessing the exploitation level of marine fishery resources. Among them the FiSAT (FAO - ICLARM Stock Assessment Tools) has been most frequently employed in estimating population parameters (Newman, 2002; Al-Barwani et al., 2007; Amin et al., 2008; Cob et al., 2009). Therefore, the present study was designed to observe the age and growth of Ficus ficoides at Thirumullaivasal coastal habitat through the application of FiSAT software.

\section{Materials and methods}

\section{Study area}

Thirumullaivasal coastal area located (Lat.: $11^{\circ} 15^{\prime} 01^{\prime \prime} \mathrm{N}$; Long.: 079 50 '29"E) in Southeast coast of Tamil Nadu, India. This landing centre is well connected by road and captured fishes were transported to the local market immediately. Every day around more than 500 trawlers are operated. They operate the trawl net at the depth of 930 meter. This study animal was caught using trawl net operation by trawlers from 9 meter depth which is about $8 \mathrm{~km}$ away from the shore line.

\section{Sample collection}

The gastropod species Ficus ficoides were collected from Thirumullaivasal coastal area. The sample was collected from January 2014 to December 2015 to observe the size frequency distribution in both male and female animals. Sampling was made randomly from 3-5 heaps contributing 50kg. Sample of the F. ficoides was collected from 1-2 heaps from single trawl net fortnightly and consolidated as monthly total.

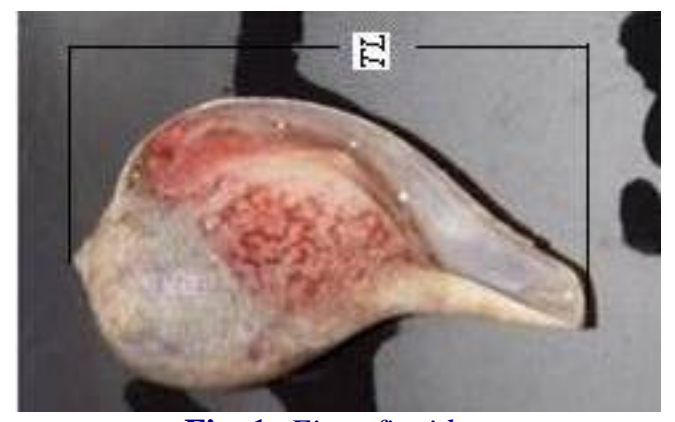

Fig. 1: Ficus ficoides.

\section{Age and growth}

Totally 1699 males and 1686 females $F$. ficoides were collected during the study period. The length of the animal (Fig. 1) was measured in millimeter from the apex to the umbilical base of the shell using a vernier caliper corrected to $0.1 \mathrm{~mm}$. care was taken to represent all the size groups. Age and growth was determined by employing the methods of Von Bertalanffy's growth equation, 1938. The data were arranged in ten sizes of groups with a class interval of $5 \mathrm{~mm}$ (Tables $1 \mathrm{a}$ and $1 \mathrm{~b}$ ).

\section{Von Bertalanffy's equation}

The mathematical equation derived by Von Bertalanffy (1938), has been used to calculate the length of animal at any given time. Beverton and Holt (1957) and Fabens (1965) have used this equation to describe the growth of organisms in various farms. This mathematical expression is useful in interpretation and also in production and computation (Pantalu, 1963; Kamala, 1969). Since growth is the net result of metabolism, a growth curve in length fits well with the growth rate of many species (Beverton, 1954; Beverton and Holt, 1957).

The present study deal here only with the Von Bertalanffy growth model of body length as a function of age. It has become one of the cornerstones in fishery biology because it is used as a sub-model in more complex models describing the dynamics of fish populations. This equation gives a linear relationship between Length $(\mathrm{L})$ at a time ' $\mathrm{t}$ ' and $(\mathrm{t}+\mathrm{x})$ is expressed as:

Where,

$$
\mathrm{Lt}=\mathrm{L}_{\infty} *\left(1-\exp \left(-\mathrm{k}^{*}\left(\mathrm{t}-\mathrm{t}_{\mathrm{o}}\right)\right)\right)
$$

Lt - Length at age ' $t$ '

$\mathrm{L}_{\infty}$ - asymptote of the growth curve in length

e - base of the natural logarithm

$\mathrm{k}$ - Co-efficient of katabolism per year

$\mathrm{t}$ - age of the animal (year)

$t_{o}$ - is hypothetical age at which the length is zero

By using this conventional method, asymptotic length or maximum length attainable was found to be $\left(\mathrm{L}_{\infty}\right)$ in millimeter, age at the origin of the growth curve (to) and co-efficient of katabolism (k) for male and female animal. The length calculated for different years using this equation was plotted along with the observed length for the same period. The "growth rate" can be defined by:

$$
\frac{\Delta \mathrm{L}}{\Delta \mathrm{t}}-\frac{\mathrm{L}(\mathrm{t}+\Delta \mathrm{t})-\mathrm{L}(\mathrm{t})}{\Delta \mathrm{t}}
$$

Time (or age), t, is usually expressed in units of year (Per Sparre and Venema, 1998). The estimated parameters $L_{\infty}$, and $\mathrm{k}$ was used to calculate the growth performance index $\left(\varphi^{\prime}\right)$ using the equation of $\Phi^{\prime}=\left(\log k+2 \log L_{\infty}\right)$ where, total length $\mathrm{L}_{\infty}$, 1/year for $\mathrm{k}$ and base10 for logarithms (Pauly and Munro, 1984). 
Table 1a. Monthly length -frequency distribution of Male (M) and female (F) Ficus ficoides at Thirumullaivasal coastal habitat during Jan-2014 to Dec-2014.

\begin{tabular}{|c|c|c|c|c|c|c|c|c|c|c|c|c|c|c|c|c|c|c|c|c|c|c|c|c|c|}
\hline \multirow{2}{*}{$\begin{array}{l}\text { Mid-total } \\
\text { length } \\
(\mathbf{m m})\end{array}$} & \multicolumn{2}{|c|}{ Jan } & \multicolumn{2}{|l|}{ Feb } & \multicolumn{2}{|c|}{ Mar } & \multicolumn{2}{|c|}{ Apr } & \multicolumn{2}{|c|}{ May } & \multicolumn{2}{|c|}{ Jun } & \multicolumn{2}{|l|}{ Jul } & \multicolumn{2}{|c|}{ Aug } & \multicolumn{2}{|c|}{ Sep } & \multicolumn{2}{|c|}{ Oct } & \multicolumn{2}{|c|}{ Nov } & \multicolumn{2}{|c|}{ Dec } & \multirow[t]{2}{*}{ Total } \\
\hline & $\mathbf{M}$ & $\mathbf{F}$ & $\mathbf{M}$ & $\mathbf{F}$ & $\mathbf{M}$ & $\mathbf{F}$ & $\mathbf{M}$ & $\mathbf{F}$ & $\mathbf{M}$ & $\mathbf{F}$ & $\mathbf{M}$ & $\mathbf{F}$ & $\mathbf{M}$ & $\mathbf{F}$ & $\mathbf{M}$ & $\mathbf{F}$ & M & $\mathbf{F}$ & M & $\mathbf{F}$ & $\mathbf{M}$ & $\mathbf{F}$ & $\mathbf{M}$ & $\mathbf{F}$ & \\
\hline $20-25$ & & & & & & & & & 1 & 1 & 1 & & & 2 & 1 & 1 & 1 & & & & & & & & 8 \\
\hline $26-30$ & & & & & & & & & 8 & 12 & 10 & 6 & 9 & 13 & 5 & 12 & 7 & & & & & & & & 82 \\
\hline $31-35$ & & & & & & & & & 5 & 6 & 5 & 4 & 6 & 7 & 5 & 7 & 5 & 2 & & & & & & & 52 \\
\hline $36-40$ & & 3 & & 2 & & & & & 3 & 4 & 3 & 0 & 3 & 8 & 2 & 6 & 1 & 15 & 2 & & 2 & & & & 54 \\
\hline $41-45$ & 5 & 9 & 5 & 7 & & & & & 2 & 7 & 5 & 5 & 5 & 5 & 4 & 12 & 7 & 7 & 10 & 4 & 10 & 4 & 5 & 3 & 121 \\
\hline $46-50$ & 7 & 5 & 5 & 6 & & & & & 4 & 3 & 5 & 0 & 2 & 5 & 11 & 6 & 8 & 14 & 19 & 5 & 10 & 10 & 7 & 15 & 147 \\
\hline $51-55$ & 7 & 7 & 22 & 9 & 14 & 19 & 10 & 17 & 2 & 0 & 4 & 1 & 4 & 6 & 6 & 0 & 4 & 7 & 12 & 2 & 10 & 0 & 7 & 0 & 170 \\
\hline $56-60$ & 14 & 23 & 26 & 16 & 20 & 18 & 15 & 33 & 2 & 7 & 5 & 2 & 1 & 6 & 3 & 18 & 4 & 10 & 10 & 10 & 10 & 14 & 14 & 15 & 296 \\
\hline $61-65$ & 9 & 14 & 28 & 11 & 14 & 18 & 9 & 10 & 3 & 0 & 4 & 0 & 6 & 9 & 2 & 5 & 3 & 7 & 5 & 13 & 7 & 16 & 9 & 12 & 214 \\
\hline $66-70$ & 32 & 8 & 22 & 20 & 20 & 25 & 16 & 24 & 3 & 2 & 1 & 4 & 2 & 1 & 6 & 5 & 8 & 6 & 25 & 9 & 26 & 13 & 32 & 10 & 320 \\
\hline $71-75$ & 24 & 16 & 17 & 9 & 19 & 20 & 5 & 20 & 2 & 0 & 2 & 1 & 2 & 10 & 5 & 3 & 8 & 10 & 11 & 17 & 17 & 11 & 24 & 15 & 268 \\
\hline Total & 98 & 85 & 125 & 80 & 87 & 100 & 55 & 104 & 35 & 42 & 45 & 23 & 40 & 72 & 50 & 75 & 56 & 78 & 94 & 60 & 92 & 68 & 98 & 70 & 1732 \\
\hline
\end{tabular}

Table 1b. Monthly length-frequency distribution of Male (M) and female (F) Ficus ficoides at Thirumullaivasal coastal habitat during Jan-2015 to Dec-2015.

\begin{tabular}{|c|c|c|c|c|c|c|c|c|c|c|c|c|c|c|c|c|c|c|c|c|c|c|c|c|c|}
\hline \multirow{2}{*}{$\begin{array}{l}\text { Mid-total } \\
\text { length } \\
(\mathrm{mm})\end{array}$} & \multicolumn{2}{|c|}{ Jan } & \multicolumn{2}{|l|}{ Feb } & \multicolumn{2}{|c|}{ Mar } & \multicolumn{2}{|c|}{ Apr } & \multicolumn{2}{|c|}{ May } & \multicolumn{2}{|c|}{ Jun } & \multicolumn{2}{|c|}{ Jul } & \multicolumn{2}{|c|}{ Aug } & \multicolumn{2}{|c|}{ Sep } & \multicolumn{2}{|c|}{ Oct } & \multicolumn{2}{|c|}{ Nov } & \multicolumn{2}{|c|}{ Dec } & \multirow[t]{2}{*}{ Total } \\
\hline & $\mathbf{M}$ & $\mathbf{F}$ & M & $\mathbf{F}$ & $\mathbf{M}$ & $\mathbf{F}$ & M & $\mathbf{F}$ & M & $\mathbf{F}$ & $\mathbf{M}$ & $\mathbf{F}$ & $\mathbf{M}$ & $\mathbf{F}$ & M & $\mathbf{F}$ & M & $\mathbf{F}$ & $\mathbf{M}$ & $\mathbf{F}$ & $\mathbf{M}$ & $\mathbf{F}$ & $\mathbf{M}$ & $\mathbf{F}$ & \\
\hline $20-25$ & & & & & & & & & 2 & 1 & 3 & 2 & 3 & 2 & 2 & 4 & 2 & & & & & & & & 21 \\
\hline $26-30$ & & & & & & & & & 6 & 8 & 8 & 4 & 5 & 10 & 4 & 6 & 4 & & & & & & & & 55 \\
\hline $31-35$ & & & & & & & & & 3 & 7 & 4 & 2 & 4 & 5 & 3 & 9 & 3 & 2 & & & & & & & 42 \\
\hline $36-40$ & & 4 & & 4 & & & & & 2 & 3 & 5 & 2 & 2 & 5 & 1 & 6 & 2 & 10 & 1 & & 3 & & & & 50 \\
\hline $41-45$ & 6 & 8 & 5 & 6 & & & & & 3 & 5 & 3 & 3 & 3 & 4 & 2 & 10 & 5 & 11 & 8 & 3 & 6 & 6 & 7 & 8 & 112 \\
\hline $46-50$ & 9 & 6 & 8 & 8 & 10 & 7 & 4 & & 6 & 5 & 3 & 4 & 2 & 6 & 10 & 7 & 6 & 10 & 15 & 6 & 6 & 8 & 8 & 10 & 164 \\
\hline $51-55$ & 7 & 6 & 20 & 7 & 12 & 17 & 9 & 15 & 6 & 4 & 4 & 2 & 3 & 5 & 4 & 2 & 3 & 9 & 10 & 4 & 8 & 5 & 6 & 6 & 174 \\
\hline $56-60$ & 13 & 10 & 23 & 14 & 19 & 10 & 13 & 24 & 5 & 5 & 6 & 3 & 1 & 7 & 2 & 15 & 2 & 8 & 12 & 8 & 9 & 11 & 12 & 12 & 244 \\
\hline $61-65$ & 8 & 13 & 23 & 9 & 13 & 16 & 10 & 11 & 4 & 4 & 8 & 3 & 4 & 9 & 3 & 8 & 4 & 9 & 7 & 11 & 8 & 12 & 6 & 10 & 213 \\
\hline $66-70$ & 29 & 10 & 20 & 21 & 18 & 23 & 14 & 19 & 3 & 2 & 7 & 3 & 2 & 6 & 4 & 5 & 6 & 11 & 21 & 11 & 22 & 15 & 29 & 11 & 312 \\
\hline $71-75$ & 21 & 14 & 18 & 11 & 20 & 19 & 9 & 18 & 5 & 2 & 9 & 0 & 2 & 10 & 3 & 3 & 5 & 8 & 9 & 17 & 14 & 13 & 20 & 16 & 266 \\
\hline Total & 93 & 71 & 117 & 80 & 92 & 92 & 59 & 87 & 45 & 46 & 60 & 28 & 31 & 69 & 38 & 75 & 42 & 78 & 83 & 60 & 76 & 70 & 88 & 73 & 1653 \\
\hline
\end{tabular}




\section{ELEFAN 1}

Electronic LEngth-Frequency ANalysis (ELEFAN) was introduced by Pauly and David (1981). This computer based entire package deals with estimation of growth parameters using length-frequency analysis. It consists of two major stages: restructuring of length-frequencies and fitting of a growth curve and therefore a score concept has been introduced to measure how close a growth curve come to the best fit.

Whenever a curve hits a bar at the axis, either positive or negative it scores points. The total score of the growth curve is the sum of the points scored from each sample (Per Sparre and Venema, 1998).

The life span $\left(\mathrm{T}_{\max }\right)$ of $F$. ficoides is estimated as per the equation: $\mathrm{T}_{\max }=3 / \mathrm{k}$ (Nagarajan, 2013).

\section{Results}

The observed and analyzed results reported in this study represent the first data on the age and growth of male and female $F$. ficoides population.

The present study growth means basically the determination of the body size as a function of age. In this study the mathematical model, expresses the length, $\mathrm{L}$, as a function of the age of the animal, $\mathrm{t}$. The equation contains the age, "t", and some parameters " $\mathrm{L}_{\infty}$ ", " $\mathrm{k}$ ", and " $t_{0}$ ".

To illustrate the use of this model, assumed that these three parameters have been estimated and that the values of male $F$. ficoides was $\mathrm{L}_{\infty}=73 \mathrm{~mm}$, for male and $74 \mathrm{~mm}$ for female, the age at the origin of the growth curve $\left(\mathrm{t}_{\mathrm{o}}\right)$ for male $2.67 \mathrm{~mm}$ and for female was 2.78 and estimated co-efficient of katabolism (k) was 0.280 and 0.282 for male and female respectively. The Von Bertalanffy's equation for growth curve may be given as follows:

$$
\begin{aligned}
& \text { In male: } \mathrm{L}(\mathrm{t})=73[1-\exp -0.280(\mathrm{t}+2.67)] \\
& \text { In female: } \mathrm{L}(\mathrm{t})=74[1-\exp -0.282(\mathrm{t}+2.78)]
\end{aligned}
$$

The length calculated for different years using this equation was plotted with the observed length for the same period, which showed a general agreement in growth curves was given in the Figs. 2 and 3. Table 2 represents the length at relative age relationship estimated using Bertalanffy's model by using $\mathrm{t}_{0}=0$.
Male attained a length of $32.93,64.05,70.9$ and $72.89 \mathrm{~mm}$ in $0.08,0.3,0.5$, and 1.08 years respectively. The females recorded a growth of $33.4,68.5,72.77$ and $73.89 \mathrm{~mm}$ in $0.08,0.4,0.7$ and 1.08 years respectively.

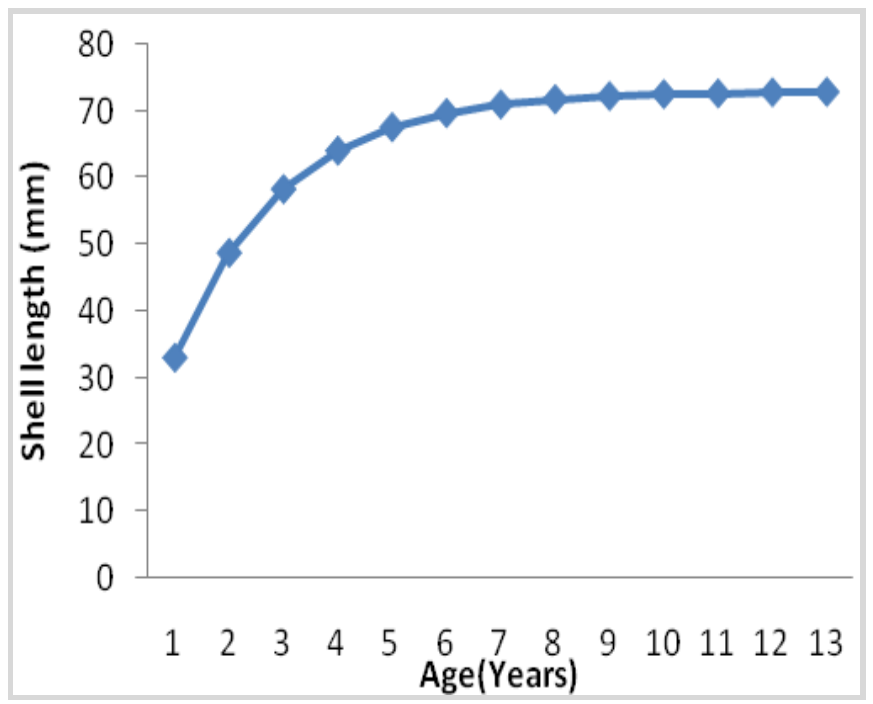

Fig. 2: VBGF length-at-age growth curve of Ficus ficoides (male) at Thirumullaivasal coast.

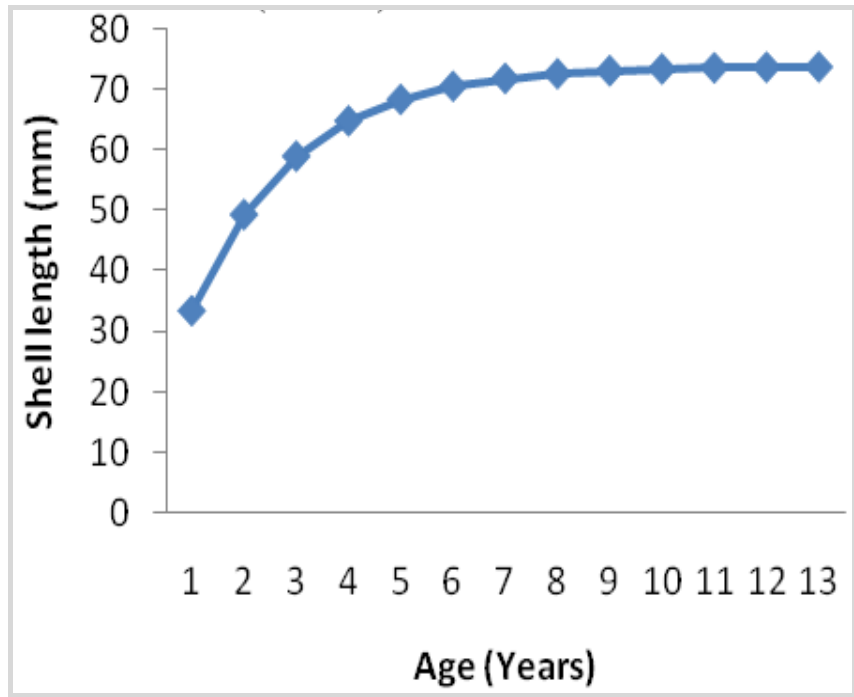

Fig. 3: VBGF length-at-age growth curve of Ficus ficoides (female) at Thirumullaivasal coast.

Animals increases in length as they grow older, but their growth rate that is the increment in length per unit time, decreases when they get older, approaching zero when they become very old.

In the present study animal it is evident that the growth rate decrease as the animal get older. The mathematical relationship between the length of the animal and the growth rate at a given time is a linear function (Table 2). 
Table 2. Estimation of age and growth by Von Bertalanffy growth model of body length as a function of age at Thirumullaivasal coastal habitat.

\begin{tabular}{|c|c|c|c|c|}
\hline \multirow{2}{*}{$\begin{array}{l}\text { RelativeAge (t) } \\
\text { (years) }\end{array}$} & \multicolumn{2}{|l|}{ Male } & \multicolumn{2}{|l|}{ Female } \\
\hline & Shell length (mm) & Growth rate $\left(\mathrm{mm}\right.$ year $\left.^{-1}\right)$ & Shell length (mm) & Growth rate $\left(\mathrm{mm} \mathrm{Year}^{-1}\right)$ \\
\hline 1 & 32.93 & 15.76 & 33.38 & 15.98 \\
\hline 2 & 48.69 & 9.57 & 49.36 & 9.70 \\
\hline 3 & 58.26 & 5.79 & 59.06 & 5.88 \\
\hline 4 & 64.05 & 3.52 & 64.94 & 3.56 \\
\hline 5 & 67.57 & 2.13 & 68.50 & 2.17 \\
\hline 6 & 69.70 & 1.29 & 70.67 & 1.31 \\
\hline 7 & 70.99 & 0.79 & 71.98 & 0.79 \\
\hline 8 & 71.78 & 0.48 & 72.77 & 0.49 \\
\hline 9 & 72.26 & 0.29 & 73.26 & 0.29 \\
\hline 10 & 72.55 & 0.11 & 73.55 & 0.18 \\
\hline 11 & 72.66 & 0.07 & 73.73 & 0.10 \\
\hline 12 & 72.83 & 0.06 & 73.83 & 0.06 \\
\hline 13 & 72.89 & 0.04 & 73.89 & 0.04 \\
\hline
\end{tabular}

The growth performance index $\left(\varphi^{\prime}\right)$ was 3.72 for male and 3.74 for female and predicted maximum length was $74.99 \mathrm{~mm}$ in male and $75.73 \mathrm{mmm}$ in female.

ELEFAN-I (Figs. 4 and 5) attempted to record a maximum for a goodness of fit function based on peaks and trough observed in this data. This is based on how often Von Bertalanffy's growth curve hits modes in the data. The length-frequency data are restructured and moving average points is identifies as a peaks. The number of peaks gives the maximum sum of peaks (ASP). Von Bertalanffy growth curve with different parameters $\left(\mathrm{L}_{\infty}\right.$, and $\left.\mathrm{k}\right)$ are run, for each trial on explained sum of peaks (ESP) is calculated. In this study the highest score obtained was $0.196\left(\mathrm{k}=0.430\right.$ year $^{-1}$; $\mathrm{Rn}=0.093, \mathrm{SL}=37.50$ ) for male and it was 0.253 $\left(\mathrm{k}=0.789\right.$ year $\left.^{-1} ; \mathrm{Rn}=0.098 ; \mathrm{SL}=42.50\right)$ for female. The goodness of fit curve obtained with these values. The life span $\left(\mathrm{T}_{\max }\right)$ of $F$. ficoides is estimated to be 3.84 years for male and 6.97years for female animal.

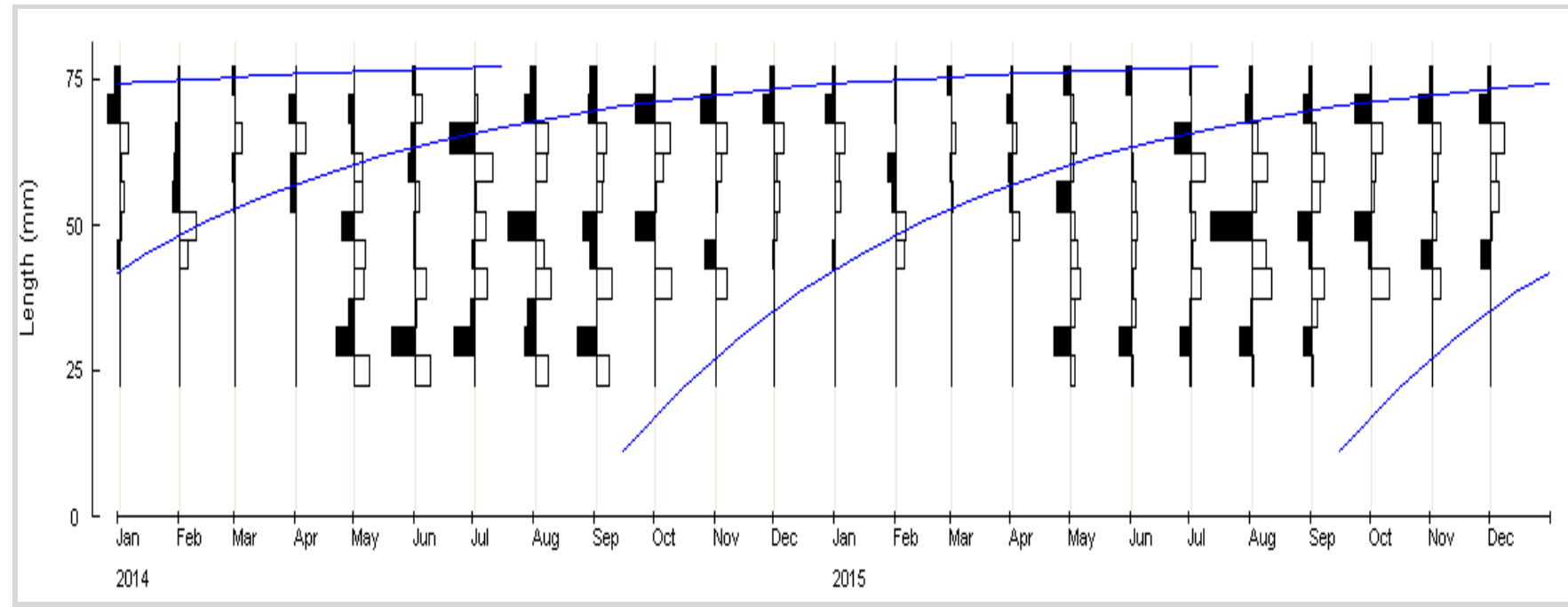

Fig. 4: Male Ficus ficoides by fitting the growth curves through the restructured length-Frequency derived by ELEFAN1 - FiSAT from Thirumullaivasal coast during Jan-2014 to Dec-2015.(Dark histogram represent frequencies that are part of "peaks" and open histogram represent "troughs" separating peaks. $)\left(\mathrm{L}_{\infty}=.78 .75, \mathrm{k}=0.780, \mathrm{SL}-=42.5\right)$. 


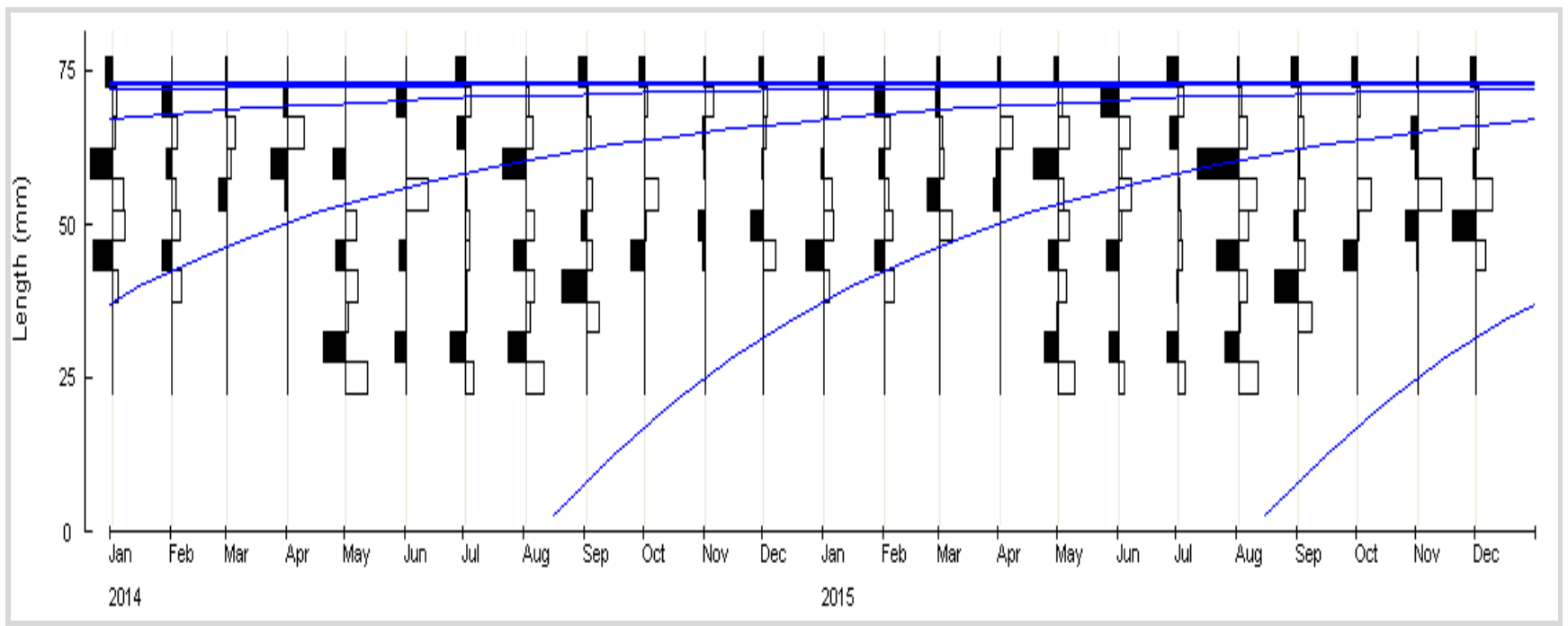

Fig. 5: Female Ficus ficoides by fitting the growth curves through the restructured length-Frequency derived by ELEFAN1 FiSAT from Thirumullaivasal coast during Jan-2014 to Dec-2015.(Dark histogram represent frequencies that are part of "peaks" and open histogram represent "troughs" separating peaks. $\left(\mathrm{L}_{\infty}=78.75, \mathrm{k}=0.430, \mathrm{SL}=37.50\right)$.

\section{Discussion}

The length based methods were involved in all fisheries. Therefore the present study estimated in comparison with existing evidences. The estimated and predicted maximum length of female $(74 \mathrm{~mm}$ and $75.73 \mathrm{~mm})$ was higher than the male $(73 \mathrm{~mm}$ and $74.99 \mathrm{~mm})$. The coefficient of growth compared where, male is $(0.280$ year ${ }^{1}$ ) lower than female $\left(0.282\right.$ years $\left.^{-1}\right)$. Cob et al, 2009 reported in his study the female animal asymptotic length and growth coefficient are higher than the male.

The growth performance Phi index $(\varphi$ ') for female was higher than the male. This $F$. ficoides study was compared and agrees with other gastropod species where it is reported female is higher than the male (Barroso et al., 2005 and Cob et al, 2009). Wolff, 1994 reported marine gastropod from all latitudes that Phi index $\left(\varphi^{\prime}\right)$ ranges between 2.2 to 4.7 , the present study ficus ficoides growth performance index observed within the range was 3.72 for male and 3.74 for female.

The Length frequency samples were repeated over every month during the study period (January 2014-December 2015) to observe the goodness of fit curve determined by the parameters of $\mathrm{L}_{\infty}, \mathrm{k}$ and $\mathrm{R}_{\mathrm{n}}$. Where $\mathrm{ESP} / \mathrm{ASP} \geq 0$. But usually $0 \leq \mathrm{ESP} / \mathrm{ASP} \leq 1$. If $\mathrm{ESP} / \mathrm{ASP} \rightarrow 1$ or $\mathrm{R}_{\mathrm{n}} \rightarrow 1$, the best goodness of fit is obtained (Pauly and Gaschutz, 1979; Chang et al., 1988; Per Sparre and Venema, 1998). In this present study it is found to be true and the best score obtained in the growth curve of $F$. ficoides was 0.196 for male and 0.253 for female.
Nagarajan (2013) reported small and medium sized animals with short life span ranging from 1.0-1.5 years with small $L \infty$ and large $k$ values. In this study it is true the life span of female $F$. ficoides is longer than the male animal with large $\mathrm{L} \infty$ and small $\mathrm{k}$ values. In the present study age and growth were estimated in comparison with existing evidences. Therefore, the validation of age determination has been put in further study.

\section{Conflict of interest statement}

Authors declare that they have no conflict of interest.

\section{Acknowledgement}

The authors would like to thank the Principal, HOD, Assistant and Associate Professors of Dept. of Zoology, TBML College, Porayer, Tamil Nadu, India.

\section{References}

Al-Barwani, S.M., Arshad, A., Amin, S. M. N., Japar, S. B., Siraj, S. S., Yap, C. K., 2007. Populaation dynamics of the green mussel Perna viridis from high spat-fall coastal water of Malacca, Peninsular Malaysis. Fish Respirat. 84, 147-152.

Amin, S. M., Zafar, M., Halim, A., 2008. Age, growth, mortality and population structure of the oyster, Crassostrea madrasensis, in the Moheskhali channel (Southeastern coast of Bangladesh). J. Appl. Ichthiol. 24, 18-25.

Barroso, C. M., Moreira, M. H., Richardson, C. A., 2005. Age and growth of Nassarius reticulatus in the Ria de Aveiro, North-Western Portugal. J. Mar. Biol. Assoc. 85, 151-156. 
Beverton, R. J. H., 1954. Notes on the use of theoretical models in the study of the dynamics of exploited fish population. U.S. Fishery Lab., Misc. Contributions, 2. 181pp.

Beverton, R. J. H., Holt, S. J. 1957. On the dynamics of exploited fish populations. Fish. Invest, Lond; Ser. 2. 19, 553 pp.

Chang, S.-K., Hsu, C.-C., Liu, H.-C., 1988. Using Length based methods to estimate Von Bertalanffy growth oarameters ofI Nemipterus parameters of North western Australian waters. ACTA oceanographic Taiwanica. No.21, 56-66.

Christensen, J.T., 1994. Growth and growth studies. Phuket Mar. Biol. Cent. (Spl. Publ.). 13, 201-204.

Cob, Z. C., Arshad, A., Bujang, J. S., Ghaffar, M. A., 2009. Age, growth, mortality and population structure of Strombus canarium (Gastropod: Strombidae): Variations in male and female sub-populations. J. Appl. Sci. 9(18), 3287-3297.

Fabens, A.J., 1965. Properties and fitting of the von Bertalanffy growth curve. Growth. 29, 265-289.

Kamala, M.Y., 1969. Studies on the age and growth of Chirrinus mrigala from the river Yamuna at Allahabad. Proc. Nat. Inst. Sci. India. 35(B), 72-92.

Liu, L.-L., Wang, S.-P., 1999. Population dynamics and mantle autotomy of the figsnail Ficus ficus (Gastropoda: Mesogastropoda: Ficidae). Zool. Stud. 38(1), 1-6.

Nagarajan, D., 2013. A study of age and growth of Secutor indicator (Bloch) from Titicorin waters of south east coast of India. Int. J. Res. Fish. Aquacult. 3(4), 122-129.
Newman, S. J., 2002. Growth, age estimation and preliminary estimates of longevity and mortality in the moses perch, Lutjanus russelli (Indian ocean form), from continental shelf waters off North-Western Australia. Asian Fish. Sci. 15, 283-294.

Pantalu, V. R. 1963. Studies on the age, growth, fecundity and spawning of the Osteogeneosus militaris. J. Cons. Perm. Int. Explor. Mer. 28, 295-315.

Pauly, D., David, N., 1981. ELEFAN-I Basic programme for the objective extraction of growth parameters from lengthfrequency data. Meersforschung. 28, 205-211.

Pauly, D., Gaschutz, G., 1979. A simple method for fitting oscillating length growth data, with a program for pocket calculator. ICES CM1979/G:24. Demersal Fish ctr. 26pp.

Pauly, D., Munro, J. L., 1984. Once more on the comparison of growth in fish and invertebrates. ICLARM, Fishbute. 2(1), 21-33.

Per Sparre, Venema, S. C., 1998. Introduction to Tropical Fish Stock Assessment. Part 1: Manual. FAO Fisheries Technical Paper, 306/1, Rev. 2.

Pitiwong, T., 1991. Population biology of gastropods. Phuket Mar. Biol. Cent. (Spl. Publ.), No.9, 117p.

Von Bertalanffy, L., 1938. A quantitative theory of organic growth (inquities on growth Laws II). Hum. Biol. 10, 181-213.

Wolff, M., 1994. Population Dynamics, Life Histories and Management of Selected Invertebrates of the Southeast Pacific Upwelling System. Habilitationsschrift University of Bremen, Bremen, Germany.

\section{How to cite this article:}

Selvi, K. G., Jeevanandham, P., 2016. Study on the age and growth of marine gastropod Ficus ficoides (Lamarck 1822) from Thirumullaivasal, southeast coast of Tamil Nadu, India. Int. J. Curr. Res. Biosci. Plant Biol. 3(6), 38-44. doi: http://dx.doi.org/10.20546/ijcrbp.2016.306.006 